\title{
Analisis Model Transformasi Hujan-Aliran pada DAS Kali Lamong dengan HEC- HMS
}

\author{
Muhammad Yusri Maulana Ikhsan ${ }^{1, *}$, Nadjadji Anwar $^{1}$, Mahendra Andiek Maulana ${ }^{1}$ \\ Departemen Teknik Sipil, Institut Teknologi Sepuluh Nopember, Surabaya ${ }^{1}$ \\ Koresponden*,Email: yus.mau97@gmail.com
}

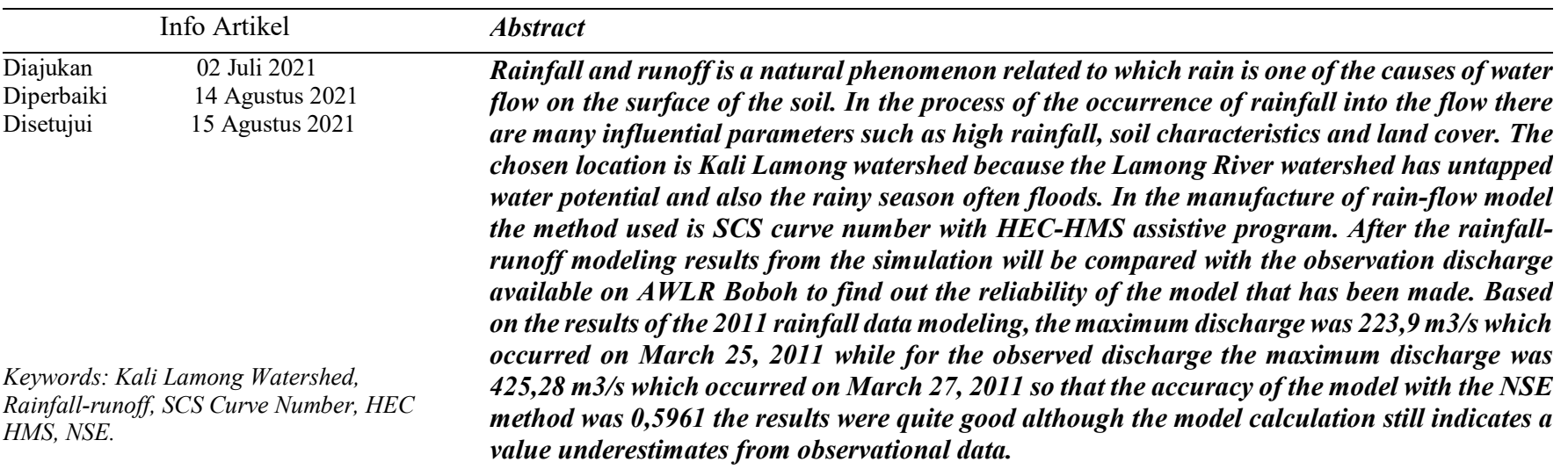

\begin{abstract}
Abstrak
Hujan dan aliran merupakan sebuah fenomena alam yang berkaitan dimana hujan merupakan salah satu penyebab terjadinya aliran air dipermukaan tanah. Dalam proses terjadinya hujan menjadi aliran terdapat banyak parameter yang berpengaruh seperti tinggi curah hujan, karakteristik tanah dan tutupan lahan. Lokasi yang dipilih adalah DAS Kali Lamong dikarenakan pada DAS Kali Lamong memiliki potensi air yang belum termanfaatkan dan juga waktu musim penghujan sering terjadi banjir. Dalam pembuatan model hujan-aliran metode yang digunakan adalah SCS curve number dengan program bantu HEC-HMS. Setelah dilakukan pemodelan hujan-aliran hasil dari simulasi akan dibandingkan dengan debit observasi yang tersedia pada AWLR Boboh untuk mengetahui tingkat akurasi dari model yang telah dibuat. Berdasarkan hasil pemodelan data hujan tahun 2011 didapatkan debit maksimum $223,9 \mathrm{~m}^{3} / \mathrm{s}$ yang terjadi pada tanggal 25 Maret 2011 sedangkan untuk debit observasi debit maksimum $425,28 \mathrm{~m}^{3} / \mathrm{s}$ yang terjadi pada 27 Maret 2011 sehingga didapat akurasi model dengan metode NSE sebesar 0,5961. Hasil yang cukup baik meskipun secara perhitungan model masih menunjukkan nilai yang dibawah perkiraan dari data observasi.
\end{abstract}

Kata kunci: DAS Kali Lamong, hujan-

debit, SCS Curve number, HEC HMS, NSE

yang akan dibangun dan akan berdampak pada tingkat

\section{Pendahuluan}

Hidrologi adalah ilmu yang berkaitan dengan air di bumi. Penerapan ilmu hidrologi dapat dijumpai dalam beberapa kegiatan seperti perencanaan dan operasi bangunan air, penyediaan air untuk berbagai keperluan (Air bersih, irigasi) dan banyak lainnya. Ilmu hidrologi lebih banyak didasarkan pada pengetahuan empiris daripada teoritis [1].

Analisis hidrologi sangat berperan penting dalam perencanaan suatu dimensi bangunan air terkait dengan debit yang akan melewati bangunan air tersebut sehingga dapat direncanakan dimensi dan umur bangunan air tersebut. Analisis hidrologi yang dimaksud adalah proses perubahan dari hujan yang turun pada suatu wilayah menjadi aliran permukaan pada suatu titik outlet. Hasil dari anlisis hidrologi berupa debit banjir yang berguna dalam penentuan dimensi bangunan keandalan dari bangunan [2].

Proses perubahan dari hujan menjadi aliran permukaan merupakan sebuah proses yang sangat rumit dikarenakan banyak faktor yang berpengaruh seperti curah hujan dan kondisi DAS sebagai media transformasi. Faktor curah hujan tergantung pada intensitas hujan, lama hujan dan sebaran hujan. Untuk faktor DAS meliputi kondisi tutupan lahan, karakteristik jaringan sungai, topografi dan jenis tanah. Dari banyaknya faktor yang ikut andil dalam proses transformasi hujan-aliran sehingga menemui kesulitan dalam analisis transformasi hujan-aliran oleh sebab itu maka tidak semua faktor dimodelkan [3].

Perhitungan analisis transformasi hujan-aliran dapat tidak dilakukan apabila data debit pada suatu titik outlet tersedia 
dengan baik. Namun di lapangan banyak dijumpai data debit pada suatu sungai tidak tersedia sama sekali ataupun tersedia dalam rentang data yang pendek [4].

Pemodelan hujan-aliran merupakan salah satu upaya untuk dapat mengetahui nilai-nilai parameter hidrologi yang terjadi di lapangan. Hasil dari pemodelan juga dapat dimanfaatkan untuk mengetahui potensi sumber daya air pada suatu wilayah DAS. Model dari hujan-aliran juga dapat dimanfaatkan sebagai early warning system seperti apabila terjadi hujan dengan intensitas tinggi maka dapat diketahui kapan akan tiba debit banjirnya.

DAS Kali Lamong sendiri memiliki potensi air permukaan yang cukup melimpah sebesar 271,63 Juta $\mathrm{m}^{3}$ berdasarkan pola PSDA Bengawan solo [5]. Dan juga beberapa kasus juga terjadi pada DAS Kali Lamong seperti banjir dan kekeringan. salah satu upaya yang dapat dilakukan adalah membuat model hidrologi hujan-aliran pada DAS Kali Lamong untuk dapat mengetahui parameter-parameter hidrologi yang terjadi di lapangan. Dalam upaya pembuatan model ini belum mempertimbangkan pengaruh pengambilan air seperti untuk air bersih dan air irigasi dikarenakan keterbatasan data yang dimiliki.

\section{Metode}

langkah-langkah dan metode yang akan digunakan dalam analisis ini dapat dijelaskan sebagai berikut:

\section{A. Analisis Data}

Dalam pembuatan model diperlukan data-data pendukung seperti data DEMNAS, data curah hujan, data debit observasi, data tutupan lahan dan data jenis tanah. Dalam pembuatan batas-batas DAS akan memanfaatkan data DEM yang diolah untuk mendapatkan aliran sungai dan batas-batas daerah aliran sungainya.

Data curah hujan yang telah diperoleh, selanjutnya dilakukan analisis berupa perhitungan curah hujan wilayah dengan metode polygon thiessen. Apabila ada kehilangan data hujan pada suatu periode tertentu perlu dilakukan perhitungan perbaikan data dengan metode reciprocal dan selanjutnya dilakukan uji konsistensi dengan metode double mass curve.

Data debit observasi didapatkan dari pengukuran secara langsung dilapangan, kondisi di DAS Kali Lamong terdapat automatic water level recorder (AWLR) di Stasiun boboh. Data yang didapat dari stasiun boboh berupa data elevasi muka air sehingga perlu melakukan perhitungan rating curve agar diketahui besaran debit yang keluar. Setelah dilakukan korelasi antara data muka air dengan rating curve akan didapatkan hidrograf observasi. Fungsi dari hidrograf observasi adalah sebagai data untuk kalibrasi model transformasi hujan-debit. Data tutupan lahan dan data jenis tanah untuk digunakan sabagai perhitungan untuk parameter metode transformasi hujan-aliran dengan SCS curve number.

\section{B. Metode SCS curve number}

Metode yang dikembangkan oleh U.S. Soil Concervation Service atau metode SCS paling banyak dimanfaatkan. Metode $S C S$ berusaha mengaitkan berusaha mengaitkan karakteristik DAS seperti jenis tanah, vegetasi dan tutupan lahan [6]. Model perhitungan limpasan ada pada persamaan 1 dan 2 [7]:
$\mathrm{Pe} \quad=\frac{(P-I a)^{2}}{P-I a+S}$
Ia $=0,2 \times S$
dengan:
excess)
P : : kedalaman hujan kumulatif pada waktu $\mathrm{t}$
Ia : $\quad$ kehilangan mula-mula (initial abstraction)
S : $\quad$ kemampuanpenyimpanan maksimum
hujan kumulatif pada waktu $\mathrm{t}$ (precipitation

Hubungan antara nilai kemampuan penyimpanan maksimum dengan nilai dari karakteristik DAS yang diwakili oleh nilai CN (Curve Number) seperti pada persamaan 3 dan 4 .

$$
\begin{array}{ll}
\mathrm{S} & =\frac{1000-10 C N}{C N}(\text { english unit }) \\
\mathrm{S} & =\frac{25400-254 C N}{C N}(S I)
\end{array}
$$

Dengan:

$\begin{array}{lll}\mathrm{S} & : & \text { Parameter retensi } \\ \mathrm{CN} & \text { Curve number }\end{array}$

Nilai dari CN (Curve Number) bervariasi dari 100 (untuk permukaan yang digenangi air) hingga sekitar 30 (untuk permukaan tak kedap air dengan nilai infiltrasi tinggi). Nilai CN dari DAS diperkirakan sebagai suatu fungsi dari tata guna lahan, tipe tanah, tanaman penutup, kelembapan dan cara pengerjaan tanah telah dikelompokkan oleh SCS menjadi empat dengan notasi A, B, C dan D. Dikarenakan pada suatu wilayah tidak hanya terdapat satu jenis tanah dan tutupan lahan maka perlu dilakukan perhitungan $\mathrm{CN}$ rata-rata. Untuk menghitung Nilai $\mathrm{CN}$ rerata dapat dihitung dengan persamaan 5 .

$$
C N \text { Composite }=\frac{\sum A i C N i}{\sum A i}
$$

Dengan:

$\begin{array}{lll}\text { CN Composite } & : & \mathrm{CN} \text { (nilai penggunaan lahan) kom- } \\ & \text { posit } \\ \mathrm{A} & : & \text { luas daerah subDAS }\end{array}$

Hidrograf SCS dapat digunakan dengan mudah, parameter utama yang dibutuhkan adalah waktu lag yaitu tenggang waktu (lag time) antara titik berat hujan efektif dengan titik 
berat hidrograf. Parameter ini didasarkan pada data dari beberapa daerah tangkapan air. Tenggang waktu (lag time) dapat ditentukan dengan rumus pada persamaan 6 dan 7 [8].

$$
\begin{aligned}
& \mathrm{t}_{\mathrm{c}}=\frac{L^{0.8}\left(\left(\frac{1000}{C N}-10\right)+10\right)^{0.7}}{1900 y^{0.5}} \\
& \mathrm{t}_{\text {lag }}=0,6 x t_{c}
\end{aligned}
$$

dengan:

$$
\begin{array}{lll}
\mathrm{L} & : & \text { Panjang sungai } \\
\mathrm{CN} & : & \text { Curve number } \\
\mathrm{Y} & : & \text { Kemiringan sungai (\%) } \\
\mathrm{t}_{\mathrm{lag}} & : & \text { Tenggang waktu (jam) } \\
\text { tc } & : & \text { Waktu konsentrasi }
\end{array}
$$

\section{Pemodelan HEC-HMS}

Dalam pemodelan hidrograf akan lebih cepat dengan bantuan perangkat lunak. Perangkat lunak yang sangat sering digunakan dalam pemodelan hidrologi adalah HEC-HMS. Program HEC-HMS merupakan program yang baik dan mudah dalam menyelesaikan perhitungan debit banjir yang bersumber dari data series hujan pada stasiun dan kurun waktu tertentu.

Dalam pembuatan model dengan HEC-HMS ada beberapa tahapan seperti basin model, meteorologic model, control specification, dan run manager. Basin model merupakan penggambaran DAS dan elemen-elemennya. Pada basin model tersusun atas gambaran fisik daerah tangkapan air dan sungai. Elemen-elemen hidrologi yang ada pada HEC-HMS yang mewaliki respon DAS terhadap presipitasi adalah subbasin, reach, junction, source, sink, reservoir dan diversion. Dalam sebuah DAS tidak harus ada dari 7 elemen tersebut, tergantung dengan karakteristik DAS. Pada penelitian ini hanya menggunakan element subbasin, reach, junction dan sink. Meteorologic model merupakan masukan data curah hujan efektif dapat berupa data hujan harian atau jam-jaman. Desain hyetograph harus didasarkan pencatatan kejadian hujan nyata. Control specification sebagai input interval waktu lama terjadi hujan. Run manager digunakan untuk mendapatkan hasil simulasi.

\section{Kalibrasi}

Untuk mengetahui kinerja dari model, selanjutnya dilakukan kalibrasi model. Data yang dibandingkan adalah debit simulasi dengan debit observasi [9]. Kalibrasi model dilakukan dengan mengubah parameter, pada penelitian ini parameter yang dicoba-coba adalah nilai curve number, initial abstraction, Imperviouss dan koefisien manning. Hasil dari kalibrasi diharapkan mengetahui bagaimana model yang da- pat menginterpretasikan sesuai dengan kondisi lapangan. Untuk kinerja model dievaluasi menggunakan NSE (Nash Sutcliffe Eficiency) perhitungan NSE seperti pada persamaan 8.

$N S E=1-\frac{\sum_{t=1}^{N}\left(Q_{S}(t)-Q_{o}(t)\right)^{2}}{\sum_{t=1}^{N}\left(Q_{S}(t)-\overline{Q_{o}}\right)^{2}}$

Dimana:

$$
\begin{array}{ll}
Q_{s}(t) & : \text { Debit Simulasi } \\
Q_{o}(t) & : \text { Debit observasi } \\
\overline{Q_{o}} & : \text { Debit observasi rata-rata } \\
N & : \text { Jumlah data }
\end{array}
$$

Indikator statistik yang paling utama dalam menentukan keakurasian model dengan NSE. Indikator ini dirasa cukup untuk mengevaluasi kinerja hasil model dengan data observasi. NSE memiliki range antara $-\infty$ sampai dengan 1 , NSE memiliki beberapa kriteria seperti yang terdapat pada Tabel 1 [10].

Tabel 1 Hubungan antara Nilai NSE terhadap Interpretasi Model.

\begin{tabular}{ll}
\hline \multicolumn{1}{c}{ Nilai NSE } & Interpretasi Model \\
(Nash-Sutcliffe Efficiency) & \\
\hline $\mathrm{NSE}>0,75$ & Baik \\
$0,36<\mathrm{NSE}<0,75$ & Memuaskan \\
$\mathrm{NSE}<0,36$ & Kurang Memuaskan \\
\hline
\end{tabular}

\section{Hasil dan Pembahasan}

A. Lokasi Studi

DAS Kali Lamong secara administrasi terletak pada 4 Kabupaten/Kota, Kabupaten Lamongan dan Kabupaten Mojokerto pada daerah hulu DAS sedangkan untuk daerah hilir berada pada Kabupaten Gresik dan Kota Surabaya dan dengan bermuara di selat Madura. DAS Kali Lamong memiliki luas DAS $\pm 720 \mathrm{~km}^{2}$ dan dengan panjang alur sungai \pm 103 $\mathrm{km}$. Pada pembahasan penelitian ini luas DAS yang diteliti sekitar 504,41 km² karena disesuaikan dengan lokasi dari AWLR Boboh. Lokasi peta batas DAS Kali Lamong dapat dilihat pada Gambar 1.

\section{B. Analisis Curah Hujan Wilayah}

Metode ini memperhitungkan bobot dari masing-masing stasiun hujan yang mewakili luasan disekitarnya. Hasil analisis pada Tabel 2 menunjukan bahwa stasiun hujan Mantup memiliki pengaruh yang terbesar pada DAS Kali Lamong yaitu bobot sebesar 0,2249 dan stasiun hujan Kedung Adem memiliki pengaruh yang kecil pada DAS Kali Lamong yaitu dengan bobot sebesar 0,0002 . 


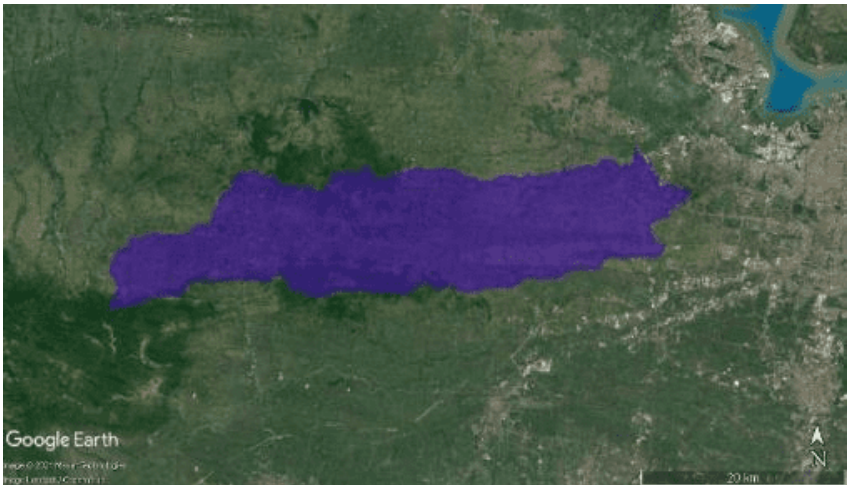

Gambar 1 Peta lokasi DAS Kali Lamong Sumber: Google Earth

Tabel 2 Perhitungan curah hujan wilayah

\begin{tabular}{|c|c|c|}
\hline Stasiun Hujan & Luasan $(\mathrm{km} 2)$ & Bobot \\
\hline Balongpanggang & 61,83 & 0,1226 \\
\hline Benjeng & 44,88 & 0,0890 \\
\hline Bluluk & 5,36 & 0,0106 \\
\hline Cerme & 1,58 & 0,0031 \\
\hline Kabuh & 14,12 & 0,0280 \\
\hline Kedung Adem & 0,11 & 0,0002 \\
\hline Kendung & 26,52 & 0,0526 \\
\hline Krikilan & 2,34 & 0,0046 \\
\hline Mantup & 113,45 & 0,2249 \\
\hline Menganti & 41,90 & 0,0831 \\
\hline Mernung & 23,93 & 0,0474 \\
\hline Ngimbang & 35,93 & 0,0712 \\
\hline Pule Kidul & 78,84 & 0,1563 \\
\hline Waduk Sempal & 8,65 & 0,0171 \\
\hline Wates & 29,09 & 0,0577 \\
\hline Wringin Anom & 15,88 & 0,0315 \\
\hline Jumlah & 504,4 & 1 \\
\hline
\end{tabular}

\section{Analisis Tutupan Lahan}

Analisis Tutupan lahan dilakukan untuk mengetahui kondisi tutupan lahan yang ada pada DAS Kali lamong. Data dari tutupan lahan didapatkan dari peta penutupan lahan tahun 2011 dari kementrian lingkungan hidup dan kehutanan. Pada Gambar 2 menunjukkan terdapat 6 (enam) jenis tutupan lahan yang ada di DAS Kali Lamong yakni: hutan, permukiman, pertanian lahan kering, pertanian lahan kering bercampur dengan semak, sawah dan tanah terbuka. Tutupan lahan pada DAS Kali Lamong didominasi oleh sawah dengan prosentase $64,14 \%$ dan hutan sebesar $24,54 \%$ dan pemukiman $9,13 \%$ untuk jenis tutupan lahan pertanian lahan kering bercampur dengan semak, pertanian lahan kering dan tanah terbuka masing masing memiliki prosentase $1,57 \%, 0,42 \%$, dan $0,19 \%$.

D. Analisis Jenis Tanah
Berdasarkan peta jenis tanah yang diperoleh, pada Gambar 3 terdapat prosentase jenis tanah yang terdapat pada DAS Kali Lamong. Jenis tanah yang dominan adalah kambisol dengan $69,01 \%$ dan jenis tanah Gleisol dengan 19,36\% dan untuk jenis tanah Grumusol, Mediteran dan Litosol masingmasing prosentasenya $8,26 \%, 3,08 \%$ dan $0,29 \%$.

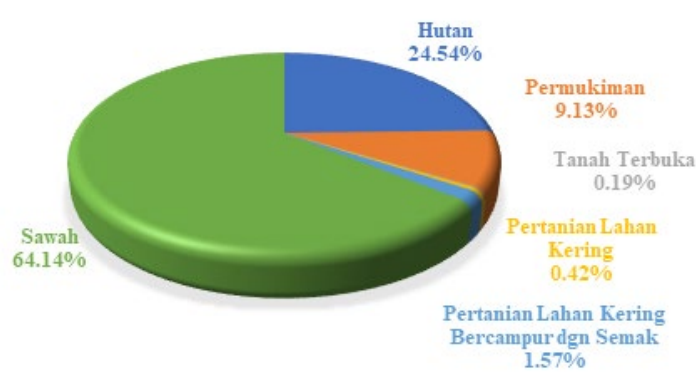

Gambar 2 Prosentase Tutupan Lahan

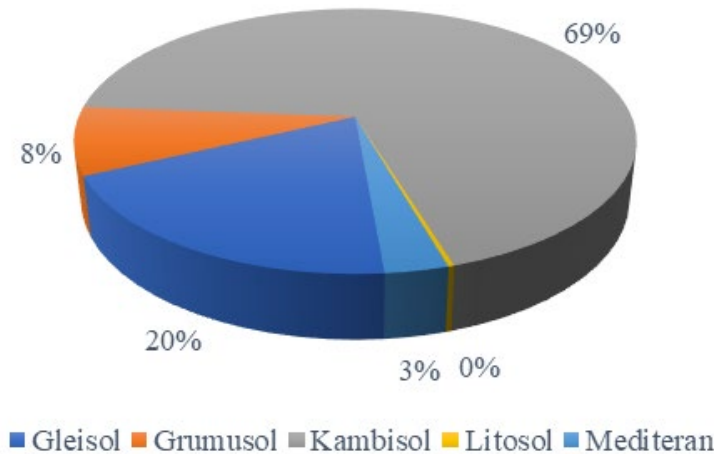

Gambar 3 Prosentase Jenis Tanah

\section{E. Pemodelan dengan HEC-HMS}

Pemodelan HEC-HMS memperlukan input data terhadap beberapa component, diantaranya basin model, meteorologic model, control specification dan time series data. Basin model digunakan untuk membuat element hidrologi yang akan mewakili kondisi di lapangan. Pada penelitian ini element hidrologi yang digunakan terdiri dari 19 Subbasin, 9 Junction, 9 reach dan 1 sink. Subbasin merupakan simbol dan fungsi dari subDAS, junction merupakan titik pertemuan dari dua atau lebih element hidrologi, reach merupakan fungsi dari sungai sebagai penghubung dari junction atau subbasin, dan sink merupakan titik outlet terakhir. Setiap element akan mewakili proses hidrologi yang terdapat pada DAS. Pada penelitian ini parameter yang digunakan dalam subbasin, loss methode menggunakan SCS Curve Number dan transform methode menggunakan SCS Unit Hydrograph dan untuk routing sungai akan menggunakan metode kinematic wave. 
F. Perhitungan Curve Number, Initial Abstraction dan Imperviouss

Curve Number merupakan fungsi dari karakteristik DAS seperti tipe tanah, dan tutupan lahan. Berdasarkan terdapat beberapa jenis tanah dan juga tutupan lahan maka perlu dilakukan perhitungan CN Composite seperti pada persamaan (5) sehingga didapatkan nila Curve number pada DAS Kali Lamong berkisar antara 72-89. Selanjutnya perhitungan Initial abstraction atau kehilangan mula mula dihitung dengan persamaan 2 didapatkan hasil pada DAS Kali Lamong nilai Initial abstraction berkisar antara 6-20 mm. Imperviouss merupakan prosentase kekedapan air pada suatu wilayah nilai Imperviouss pada masing-masing sub DAS berkisar antara 7 $-30 \%$.

\section{G. Perhitungan Time lag}

Metode SCS curve number membutuhkan nilai time lag untuk menentukan lama perjalanan runoff. Time lag merupakan waktu perjalanan yang diperlukan oleh air dari tempat terjauh sampai ke titik pengamatan. Proses perhitungan time lag menggunakan persamaan 7 didapatkan nilai time lag pada DAS Kali Lamong 7-214 menit.

\section{H. Hasil Pemodelan}

Setelah penyusunan model selesai dilakukan, tahap selanjutnya adalah running model. Tujuan dari running model adalah untuk memproses semua data yang parameter yang dimasukkan sehingga akan menjadi data hasil simulasi. Pada Gambar 4 merupakan gabungan antara grafik debit simulasi dan debit observasi dengan konfigurasi data hujan tahun 2011. Selanjutnya dilakukan perhitungan NSE untuk mengetahui goodness of fit dari model.

Hasil simulasi pada Gambar 4 menunjukan bahwa debit simulasi sudah cukup bagus seperti debit observasi berdasarkan nilai NSE sebesar 0,495. Dengan curah hujan maksimum sebesar 48,24 mm menghasilkan debit puncak pada hidrograf simulasi terjadi pada tanggal 24 Maret 2011 dengan debit $231,4 \mathrm{~m}^{3} / \mathrm{s}$. Sedangkan pada debit observasi, debit puncak terjadi pada tanggal 27 Maret 2011 dengan debit 425,3 m3/s. Langkah selanjutnya adalah kalibrasi parameter untuk membuat nilai NSE antara model simulasi dengan debit observasi menjadi lebih baik seperti pada Tabel 1.

Kalibrasi merupakan langkah untuk membuat hasil model mendekati kondisi di lapangan. Proses kalibrasi ini juga dapat dimanfaatkan untuk mengetahui kesesuaian dari estimasi parameter-parameter yang digunakan. Setiap parameter memiliki sensitivitas yang berbeda beda, dengan membandingkan nilai debit simulasi dengan debit observasi dapat di- ketahui besar sensitivitas dari masing-masing parameter. Dalam penelitian ini kalibrasi parameter yang dilakukan adalah mencoba merubah nilai dari curve number sehingga menyebabkan perubahan nilai initial abstraction, imperviouss, dan time lag. Selain itu ada parameter lain yang dicoba untuk diubah yakni adalah koefisien manning sebagai nilai dari parameter pada proses perhitungan routing sungai seperti pada Tabel 3.

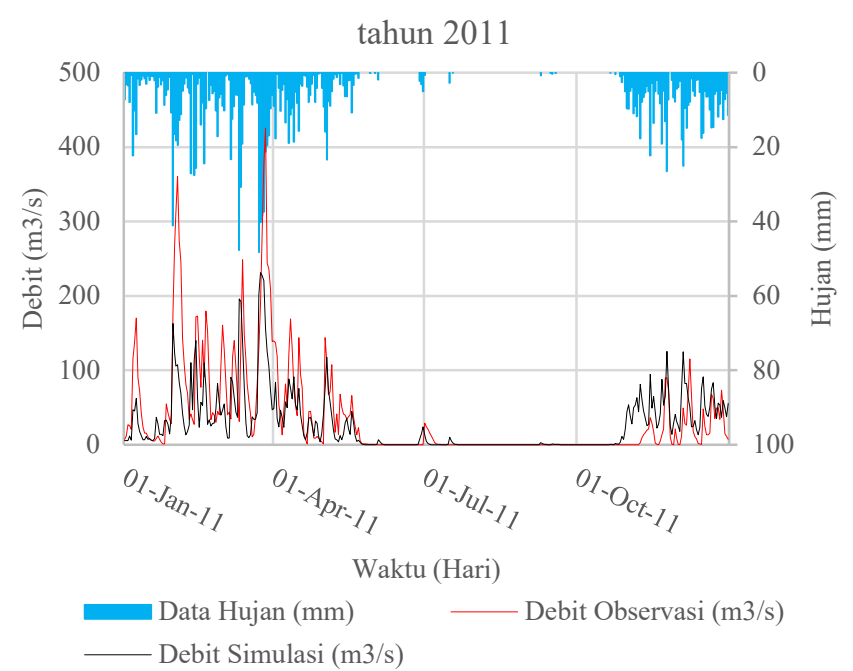

Gambar 4 Grafik perbandingan debit simulasi dengan debit observasi tahun 2011

Setelah dilakukan kalibrasi hasil dari model simulasi didapatkan grafik perbandiang antara model simulasi dan debit observasi terdapat pada Gambar 5. data hujan tahun 2011 curah hujan maksium sebesar $48 \mathrm{~mm}$ didapatkan hasil simulasi debit maksium terjadi pada tanggal 25 Maret 2011 sebesar $223,9 \mathrm{~m}^{3} / \mathrm{s}$ sedangkan debit observasi tertinggi terjadi pada tanggal 27 Maret 2011 dengan debit 425,28 m³. Hasil kalibrasi menunjukkan nilai NSE 0,5961 berdasarkan Tabel 1 interpretasi dari model adalah memuaskan sehingga dapat dilakukan perhitungan selanjutnya.

Setelah mendapatkan model yang sesuai kriteria dengan nilai NSE yang memuaskan, selanjutnya dilakukan perhitungan dengan variasi input data curah hujan untuk mengetahui respon dari model terhadap curah hujan yang terjadi. Variasi data curah hujan yang digunakan adalah data tahun 2012 sampai dengan tahun 2014.

Pada Gambar 6 data hujan tahun 2012 curah hujan maksimum sebesar $35 \mathrm{~mm}$ didapatkan hasil simulasi debit puncak terjadi pada tanggal 27 Desember 2012 Sebesar $126 \mathrm{~m}^{3} / \mathrm{s} \mathrm{se}$ dangkan debit observasi tertinggi terjadi pada tanggal $13 \mathrm{Ja}$ nuari 2012 dengan debit $217,40 \mathrm{~m}^{3} / \mathrm{s}$ sehingga didapat nilai NSE 0,5165. 
Tabel 3 Perbandingan parameter kondisi awal dan hasil kalibrasi

\begin{tabular}{crrr}
\hline \multirow{2}{*}{ Parameter model } & & \multicolumn{2}{c}{ Nilai Parameter } \\
\cline { 3 - 4 } & & $\begin{array}{c}\text { Kondisi } \\
\text { Awal }\end{array}$ & $\begin{array}{c}\text { Hasil } \\
\text { Kalibrasi }\end{array}$ \\
\hline \multirow{2}{*}{ Curve Number } & Min & 71,98 & 84,79 \\
Initial Abstraction & Min & 88,97 & 93,10 \\
(mm) & Max & 6,30 & 3,77 \\
Imperviouss (\%) & Min & 7,50 & 9,11 \\
Time Lag (Min) & Max & 29,64 & 82,40 \\
& Min & 7,72 & 7,40 \\
Koefisien manning & Max & 214,20 & 159,75 \\
& Min & 0,025 & 0,035 \\
& Max & 0,025 & 0,160 \\
\hline
\end{tabular}

tahun 2011

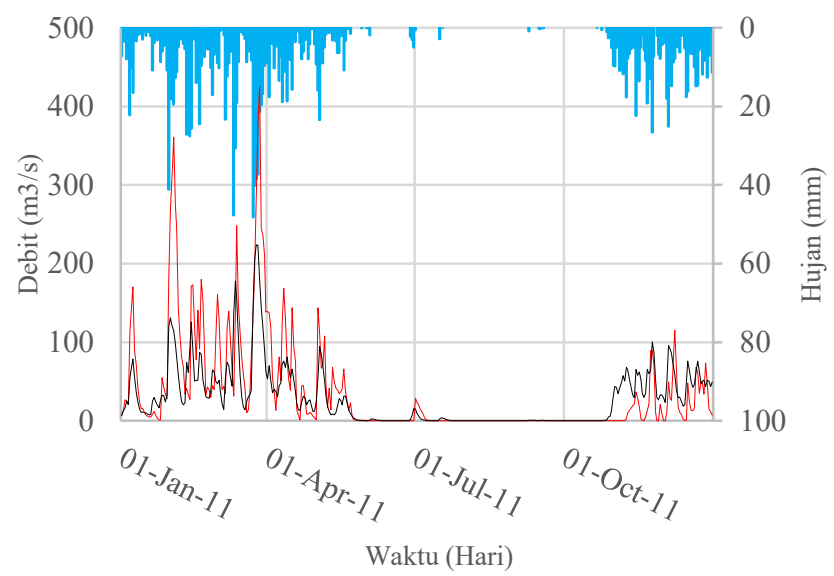

Data Hujan (mm) Debit Observasi (m3/s)

Gambar 5 Grafik perbandingan debit observasi dengan debit simulasi setelah kalibrasi

Pada Gambar 7 data hujan tahun 2013 curah hujan maksimum sebesar $40 \mathrm{~mm}$ didapatkan hasil simulasi debit puncak terjadi pada tanggal 15 Desember 2013 Sebesar 178,2 $\mathrm{m}^{3} / \mathrm{s}$ sedangkan debit observasi tertinggi terjadi pada tanggal 20 Maret 2013 dengan debit 300,96 m³ s sehingga didapat nilai NSE 0,2729.

Pada Gambar 8 data hujan tahun 2014 curah hujan maksimum sebesar $49 \mathrm{~mm}$ didapatkan hasil simulasi debit puncak terjadi pada tanggal 19 Desember 2014 Sebesar 212,9 m³ sedangkan debit observasi tertinggi terjadi pada tanggal 21 Desember 2014 dengan debit 290,15 m³ s sehingga didapat nilai NSE 0,5211 . tahun 2012

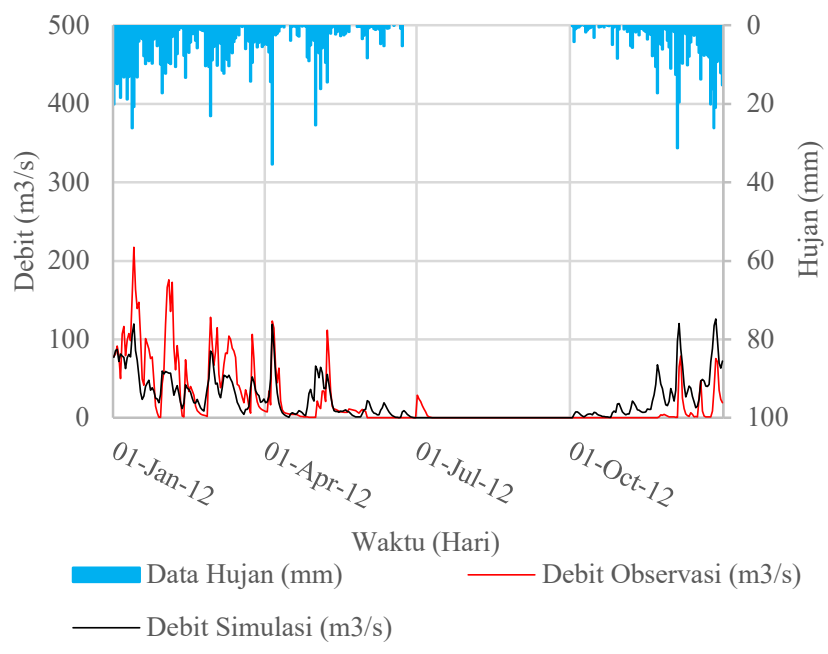

Gambar 6 Grafik perbandingan debit simulasi dengan debit observasi tahun 2012

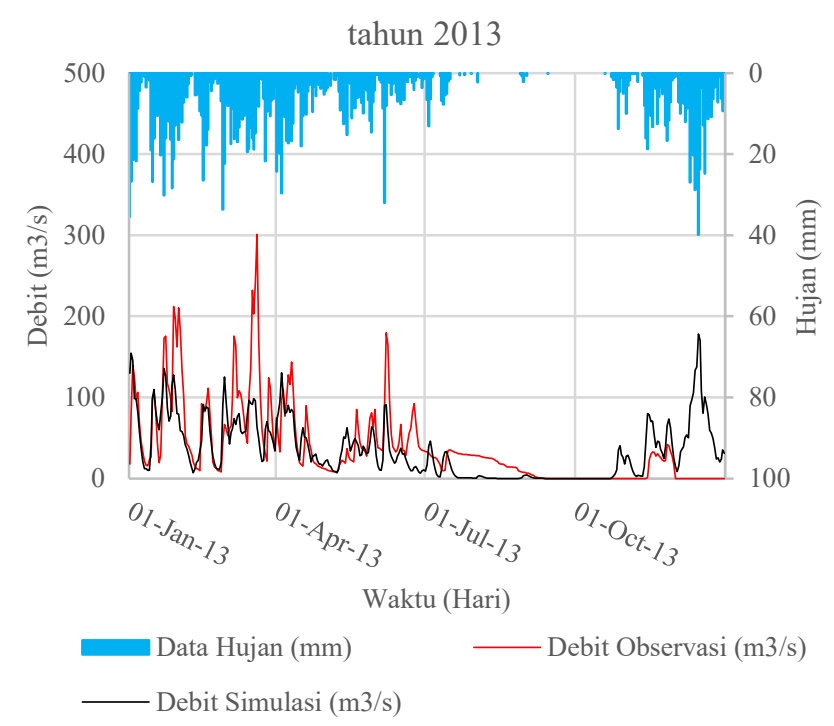

Gambar 7 Grafik perbandingan debit simulasi dengan debit observasi tahun 2013

\section{Simpulan}

Berdasarkan hasi pembahasan maka dapat diambil kesimpulan, antara lain:

1. Hasil pemodelan hujan-debit pada kondisi awal menghasilkan debit puncak terjadi pada tanggal 24 Maret 2011 dengan debit sebesar $231,4 \mathrm{~m}^{3} / \mathrm{s}$ dengan nilai NSE sebesar 0,4950, setelah dilakukan kalibrasi hasil hidrograf simulasi debit puncak terjadi pada tanggal 25 Maret 2011 dengan debit sebesar $223,9 \mathrm{~m}^{3} / \mathrm{s}$ dengan akurasi nilai NSE 0,5961 . 
2. Hasil model untuk data hujan tahun 2012 hasil simulasi debit puncak terjadi pada tanggal 27 Desember 2012 sebesar $126 \mathrm{~m}^{3} / \mathrm{s}$ dengan akurasi nilai NSE 0,5165.

3. Hasil model untuk data hujan tahun 2013 didapatkan hasil simulasi debit puncak terjadi pada tanggal 15 Desember 2013 Sebesar 178,2 m³ $/ \mathrm{s}$ dengan nilai NSE 0,2729.

4. Hasil model untuk data hujan tahun 2014 hasil simulasi debit puncak terjadi pada tanggal 19 Desember 2014 sebesar $212,9 \mathrm{~m}^{3} / \mathrm{s}$ dengan nilai NSE 0,5211.

5. Hasil perhitungan NSE menunjukkan model dengan data curah hujan tahun 2011 menunjukan hasil terbaik dengan nilai NSE yakni 0,5961 meskipun secara perhitungan model masih menunjukkan nilai yang underestimate dari data observasi.

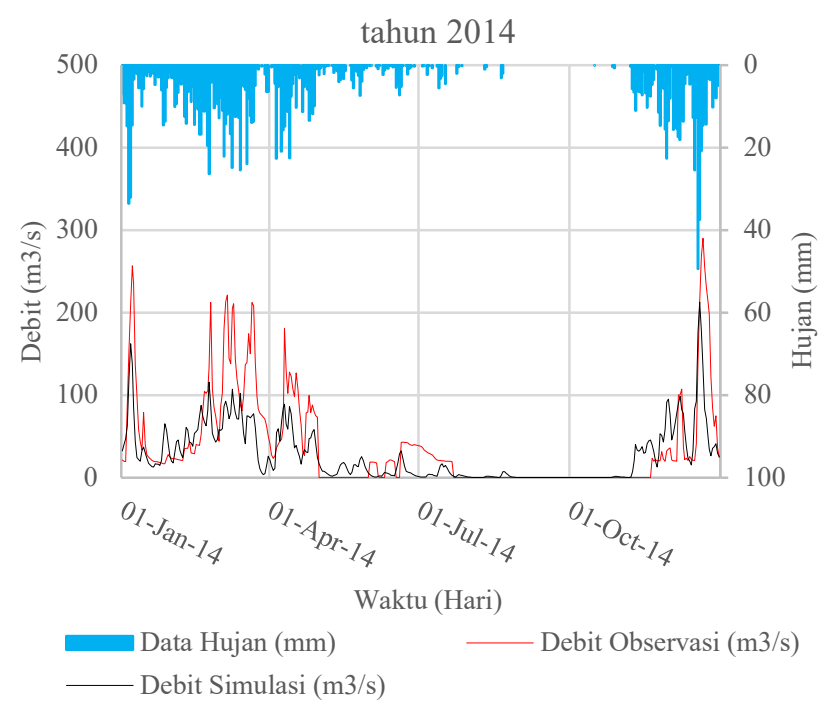

Gambar 8 Grafik perbandingan debit simulasi dengan debit observasi tahun 2014

\section{Daftar Pustaka}

[1] Triatmodjo. Bambang, Hidrologi Terapan, Cetakan
Pertama. Yogyakarta: Beta Offset, 2008.

[2] Harto, Sri., Analisis Hidrologi, Jakarta, PT Gramedia Pustaka Utama, 1993

[3] Tunas, I.G "Pengembangan Model Hidrograf Satuan Sintetik Berdasarkan Karakteristik Fraktal Daerah Aliran Sungai," Surabaya, 2017.

[4] Salami, A.W., Bilewu, S.O., Ayanshola, A.M., Oritola, S.F., "Evaluation of Synthetic Unit Hydrograph Methods for The Development of Design Storm Hydrographs for Rivers in South-West Nigeria," Journal of American Science, vol. 5, no. 4, p. 23-32, 2009.

[5] Keputusan Menteri Pekerjaan Umum Republik Indonesia Nomor 266/KPTS/M/2010 Tentang Pola Pengelolaan Sumber Daya Air Wilayah Sungai Bengawan Solo

[6] Asdak,C , Hidrologi dan Pengelolaan Daerah Aliran Sungai, Cetakan keempat. Yogyakarta: Gadjah Mada University Press, 2007.

[7] US Army Corps of Engineers," HEC-HMS Hydrologic Modeling System : Technical Reference Manual." Washington DC. 2000.

[8] Wanielista,M., R.Kersten, dan R. Eaglin , Hydrology:Water Quantity and Quality Control,. New York: Jhon Wiley and Sons Inc, 1997.

[9] Cheng, C., Cheng, S., Wen, J., and Lee, J., "Time and Flow Characteristics of Component Hydrographs Related to Rainfall-Streamflow Observations," Journal of Hydrologic Engineering, vol. 18, no. 6, p. 675-678, 2013.

[10] Motovilov, Y.G., Gottschalk, L., Engeland, K.\& Rodhe, A. "Validation of a Distributed Hydrological Model Against Spatial Observations" Elsevier Agricultural and Forest Meteorology,Vol 98-99 p.257-277,1999. 
Halaman ini sengaja dikosongkan 